\title{
Model approach for estimating potato pesticide bioconcentration factor
}

\author{
Lourival Costa Paraíba ${ }^{\mathrm{a}, *}$, Karen Kataguiri ${ }^{\mathrm{b}}$ \\ ${ }^{a}$ Embrapa Meio Ambiente, Embrapa Environment, CXP. 69, CEP 13820-000, Jaguariúna, São Paulo, Brazil \\ ${ }^{\mathrm{b}}$ Faculdade de Engenharia Ambiental, Universidade Estadual de São Paulo, UNESP. Av. Três de Março, n.511, 18087-180, Sorocaba, São Paulo, Brazil
}

\section{A R T I C L E I N F O}

\section{Article history:}

Received 11 February 2008

Received in revised form 11 July 2008

Accepted 14 July 2008

Available online 26 August 2008

\section{Keywords:}

$\mathrm{BCF}$

Daily ingestion

Bioaccumulation

Food diet

Insecticide

Fungicide

\begin{abstract}
A B S T R A C T
We presented a model that estimates the bioconcentration factor (BCF) of pesticides in potatoes supposing that the pesticide in the soil solution is absorbed by the potato by passive diffusion, following Fick's second law. The pesticides in the model are nonionic organic substances, traditionally used in potato crops that degrade in the soil according to a first-order kinetic equation. This presents an expression that relates $\mathrm{BCF}$ with the pesticide elimination rate by the potato, with the pesticide accumulation rate within the potato, with the rate of growth of the potato and with the pesticide degradation rate in the soil. BCF was estimated supposing steady state equilibrium of the quotient between the pesticide concentration in the potato and the pesticide concentration in the soil solution. It is suggested that a negative correlation exists between the pesticide BCF and the soil sorption partition coefficient. The model was built based on the work of Trapp et al. [Trapp, S., Cammarano, A., Capri, E., Reichenberg, F., Mayer, P., 2007. Diffusion of $\mathrm{PAH}$ in potato and carrot slices and application for a potato model. Environ. Sci. Technol. 41 (9), $3103-$ 3108], in which an expression to calculate the diffusivity of persistent organic substances in potatoes is presented. The model consists in adding to the expression of Trapp et al. [Trapp, S., Cammarano, A., Capri, E., Reichenberg, F., Mayer, P., 2007. Diffusion of PAH in potato and carrot slices and application for a potato model. Environ. Sci. Technol. 41 (9), 3103-3108] the hypothesis that the pesticide degrades in the soil. The value of BCF suggests which pesticides should be monitored in potatoes.
\end{abstract}

(C) 2008 Elsevier Ltd. All rights reserved.

\section{Introduction}

Potato plants are cultivated in more than one hundred countries from different continents because of their extraordinary adapting capacity to different climatic and soil conditions, only being surpassed by wheat, rice and corn, and more than one billion people consume these tubers. The potato's agronomic efficiency guarantees the use of several types of soils destined to food production, which contributes to increase the potato cropping area in a global scenario of rapid population growth and economic development. In Brazil, the potato is pointed out as the main root tuber, with a cultivated area larger than one hundred and forty thousand hectares. The production in 2005 was of two million tons IBGE (2008). All over the world, the main limiting factor to potato cropping is its susceptibility to a great number of pests and diseases, some of them capable of causing serious production damages, which impose the use of many and several types of pesticides, causing serious environmental and feeding problems (Caldas et al., 2004; López-Pérez et al., 2006; Leistra and Van Den Berg, 2007). Even by taking into account that the most recent agronomic management techniques, suggested by the integrated production systems reduce risks of environmental

\footnotetext{
* Corresponding author. Tel.: +55 193311 2667; fax: +55 1933112640 .

E-mail address: lourival@cnpma.embrapa.br (L.C. Paraíba).
}

and feeding contamination, it is fundamental that managers, technicians and researchers know how to estimate the accumulative potential of pesticides in potatoes, enabling them to recommend new products and technologies in order to have economically and environmentally sustainable productions.

Potatoes are low in fat and are rich in several micronutrients. Sized potato of $150 \mathrm{~g}$ provides nearly half the daily adult requirement $(100 \mathrm{mg})$. They are a moderate source of iron, and its high vitamin $C$ content promotes iron absorption and a good source of vitamins B1, B3 and B6 and minerals such as potassium, phosphorus and magnesium, and contains folate, pantothenic acid and riboflavin. Potatoes also contain dietary antioxidants, which may play a part in preventing diseases related to ageing, and dietary fiber, which benefits health. The UN FAO (United Nations Food and Agriculture Organization) is currently promoting the tuber as a more efficient food crop that can improve food security in developing countries. About $80 \%$ of the potato crop can be used for human consumption, significantly more than for cereals like corn and wheat.

The bioconcentration of a substance in an organism is a process that describes the increase of the concentration of the substance in the organism in relation to the concentration of the substance in the medium. The bioconcentration factor (BCF) of a substance in an organism is a numeric value that measures the bioconcentration 
and expresses the partition of the substance between the organism and the medium. In the chemical steady state equilibrium, this coefficient is the quotient between the pesticide concentration in the organism and the pesticide concentration in the medium. As in every partition coefficient, the BCF does not also depend on dose or on the concentration in medium, and should always be estimated by the limit in time of the quotient between the concentration of the substance in the organism and the concentration of the substance in medium (EPA, 1996; Paraíba, 2007). When the organisms are cultivated foods, BCF permits an approximation of the pesticide's daily ingestion through its food consumption and establishes safe limits for pesticide concentrations in medium and indicates which pesticides should be monitored in the food.

A classic experimental procedure used to estimate a pesticide BCF in fish consists of exposing a fish test group to a constant pesticide concentration in the water, until the quotient between the concentration of the pesticide in the fish and the concentration of the pesticide in the water reaches a steady state, this is the accumulation phase, that is followed by an elimination phase of the pesticide in which the previously contaminated fish are put in clean water and the pesticide concentrations are monitored. The experimental data concentrations obtained in both phases make it possible to calculate BCF by the quotient between the pesticide accumulation and elimination rates (OECD, 1996). However, this procedure presents two main difficulties: keeping a constant concentration in water during the accumulation phase, and previously determining the time required to reach the steady state. The difficulties are even greater when the organisms are potato plants. It is not easy to maintain a constant concentration in the soil and later transport the contaminated potato plants to an appropriate pesticide-free soil.

Most pesticides have a low or moderate persistence in the soil, when compared with persistent organic pollutants. For this reason, a model that takes into account that a constant concentration of pesticides in the soil is not, in itself, adequate to estimate BCF in potatoes of pesticides degrading in the soil. The experimental procedure, and respective mathematical model, must not only incorporate the degradation of the pesticide in the soil, it must also describe a hypothetical situation in which it's not necessary to accomplish the transplant of polluted potatoes to a pesticide free soil. The model should also simulate concentrations of pesticides in the soil solution and in the potato, so that these can be used to estimate the BCF, calculating the quotient's steady state between the concentrations in the potato and in the soil solution.

Several studies indicate the presence of pesticides and organic substances in potatoes (Dogheim et al., 2002; Fismes et al., 2002; Samsoe-Petersen et al., 2002; Jensen et al., 2003; Poulsen and Andersen, 2003; Rissato et al., 2005; Cesnik et al., 2006; Zohair et al., 2006) but none of them present a theoretically acceptable and experimentally model that one can use to estimate BCF in potatoes of pesticides degrading in the soil. Thus, the objective of this work was to model the kinetics of pesticide uptake for potatoes, to use this model to estimate BCF in potato pesticides frequently used in this cultivation and to indicate which of them should be monitored in potato samples. For hypothesis, the studied pesticides are nonionic organic substances that degrade in the soil, following a first-order kinetic equation. The model was built based on the work of Trapp et al. (2007) in which Fick's second law is used for modeling the diffusive flow of the pesticide through the potato tissues. The work of Trapp et al. (2007) suggests that the mass transfer through the potato tissue occurs predominantly by the soil solution. The model developed by Trapp et al. (2007) makes it possible to estimate the diffusivity of organic substances in soil for potatoes, and helps significantly to elaborate useful mathematical models to determine the potato's bioconcentration factor of nonionic pesticides degrading in the soil.

\section{Materials and methods}

Pesticide concentration in the soil surrounding the potato was taken into account describing the equation below

$C_{s}(t)=C_{s}(0) \mathrm{e}^{-k_{s} t}$

where $C_{\mathrm{s}}\left(\mathrm{mg} \mathrm{kg}^{-1}\right)$ is the pesticide concentration in soil, $C_{\mathrm{s}}(0)$ $\left(\mathrm{mg} \mathrm{kg}^{-1}\right)$ is the initial pesticide concentration in soil and $k_{\mathrm{s}}\left(\mathrm{day}^{-1}\right)$ is the pesticide degradation rate in the soil estimated by, $k_{\mathrm{s}}=0.693 /$ $t_{1 / 2}$, in which $t_{1 / 2}$ (day) is the half-life pesticide in the soil.

From the pesticide concentration in the soil, Eq. (1), the pesticide concentration in the soil solution was estimated by

$C_{\mathrm{w}}(t)=\frac{\rho_{\mathrm{w}} C_{\mathrm{s}}(0) \mathrm{e}^{-k_{\mathrm{s}} t}}{\left(\rho_{\mathrm{s}} f_{\mathrm{oc}} K_{\mathrm{oc}}+f_{\mathrm{w}}+f_{\mathrm{a}} K_{\mathrm{aw}}\right)}$

where $\rho_{\mathrm{w}}\left(\mathrm{kg} \mathrm{L}^{-1}\right)$ and $\rho_{\mathrm{s}}\left(\mathrm{kg} \mathrm{L}^{-1}\right)$ are the soil densities in a humid and dry basis, respectively. The $f_{\mathrm{oc}}, f_{\mathrm{w}}$ and $f_{\mathrm{a}}$ coefficients are the volumetric fractions of organic carbon, water and air of the soil, respectively. $K_{\mathrm{oc}}\left(\mathrm{L} \mathrm{kg}^{-1}\right)$ is the soil sorption partition coefficient of the pesticide and $K_{\mathrm{aw}}$ is air-water partition coefficient of the pesticide estimated by

$K_{\mathrm{aw}}=\frac{P_{\mathrm{v}} \times P_{\mathrm{m}}}{S \times R \times(273+T)}$

where $\left(T=25^{\circ} \mathrm{C}\right)$ is the air temperature $\left(R=8.314 \mathrm{~Pa} \mathrm{~m}^{3} \mathrm{~mol}^{-1} \mathrm{~T}^{-1}\right)$ is the gas constant, $P_{\mathrm{v}}(\mathrm{Pa})$ is the pesticide vapor pressure, $P_{\mathrm{m}}$ $\left(\mathrm{g} \mathrm{mol}^{-1}\right)$ is the pesticide molar mass and $S\left(\mathrm{~g} \mathrm{~m}^{-3}\right)$ is the pesticide water solubility.

The uptake and elimination of pesticides from surrounding medium into a potato can be described by a compartment system given by

$\frac{\mathrm{d} C_{\mathrm{p}}}{\mathrm{d} t}=k_{\mathrm{u}} C_{\mathrm{w}}-\left(k_{\mathrm{e}}+k_{\mathrm{g}}\right) C_{\mathrm{p}}$

where $C_{\mathrm{p}}\left(\mathrm{mg} \mathrm{kg}^{-1}\right)$ is the pesticide concentration in the potato, $k_{\mathrm{u}}$ $\left(\mathrm{L} \mathrm{kg}^{-1} \mathrm{day}^{-1}\right)$ is the pesticide uptake rate by potato, $k_{\mathrm{e}}\left(\mathrm{day}^{-1}\right)$ is the pesticide elimination rate by potato and $k_{\mathrm{g}}\left(\mathrm{day}^{-1}\right)$ is the potato growth rate.

The pesticide uptake rate was estimated supposing a passive diffusion of the pesticide by potato from soil solution with diffusion coefficient given by (Fick's second law; Trapp et al., 2007)

$k_{\mathrm{u}}=\frac{23 D_{\mathrm{p}}}{r^{2} \rho_{\mathrm{p}} K_{\mathrm{sw}}}$

where $D_{\mathrm{p}}\left(\mathrm{m}^{2}\right.$ day $\left.^{-1}\right)$ is the effective diffusion coefficient of pesticide by potato tissue, $r(\mathrm{~m})$ is the radius of the potato, $\rho_{\mathrm{p}}\left(\mathrm{kg} \mathrm{L}^{-1}\right)$ is the density of the potato and $K_{\mathrm{sw}}$ (dimensionless) is the soilwater partition coefficient of the pesticide. The potato density is necessary to correctly define the pesticide uptake rate with unity of $\mathrm{L} \mathrm{kg}^{-1} \mathrm{day}^{-1}$ and to produce the bioconcentration factor with units of $\mathrm{L} \mathrm{kg}^{-1}$, and also, the pesticide uptake rate is inversely proportional to the potato's density (Crank, 1975). The dimensionless soil-water partition coefficient of the pesticide was calculated by

$K_{\mathrm{sw}}=\rho_{\mathrm{s}} f_{\mathrm{oc}} K_{\mathrm{oc}}+f_{\mathrm{w}}+f_{\mathrm{a}} K_{\mathrm{aw}}$

The pesticide effective diffusion coefficient by potato tissue was estimated by

$D_{\mathrm{p}}=p_{\mathrm{w}} T_{\mathrm{w}} D_{\mathrm{w}}$

where $T_{\mathrm{w}}$ is a tortuosity coefficient to account for the porosity of the soil, and $p_{\mathrm{w}}$ (dimensionless) is the volumetric fraction of pesticide dissolved in the water phase of potato tissue, calculated by $p_{\mathrm{w}}=w_{\mathrm{p}} / K_{\mathrm{pw}}$, in which $w_{\mathrm{p}}$ is the pore water fraction in the potato tissue, $D_{\mathrm{w}}\left(\mathrm{m}^{2}\right.$ day $\left.^{-1}\right)$ is the pesticide diffusivity in water or soil solution estimated by 
$D_{\mathrm{w}}=\frac{4.93 \times 10^{-6} T \sqrt{\phi_{\mathrm{w}} w_{\mathrm{m}}}}{\mu_{\mathrm{w}}\left(v_{\mathrm{m}}\right)^{0.6}}$

where $\varphi_{\mathrm{w}}=2.6$ is an association term for the solvent (water), $w_{\mathrm{m}}=18 \mathrm{~g} \mathrm{~mol}^{-1}$ is the molar mass of the water, $\mu_{\mathrm{w}}=8.9 \times 10^{-1}$ $\mathrm{cp}$ is the water viscosity, and $v_{\mathrm{m}}\left(\mathrm{cm}^{3} \mathrm{~mol}^{-1}\right)$ is the molar volume of the pesticide (Clark, 1996).

The pesticide elimination rate by potato was estimated supposing a passive diffusion of the pesticide by soil solution from potato with diffusion coefficient given by (Fick's second law; Trapp et al., 2007)

$k_{\mathrm{e}}=\frac{23 D_{\mathrm{p}}}{r^{2} K_{\mathrm{pw}}}$

where $K_{\mathrm{pw}}$ (dimensionless) is the potato-water partition coefficient of the pesticide estimated by equation given by (Trapp et al., 2007)

$K_{\mathrm{pw}}=w_{\mathrm{p}}+\mathrm{CH}_{\mathrm{p}} \times K_{\mathrm{ch}}+0.8197 \times l \times\left(K_{\mathrm{ow}}\right)^{0.77}$

where $\mathrm{CH}_{\mathrm{p}}$ and $l$ are the volumetric fractions of carbohydrate and lipid of the potato tissue, respectively. $K_{\mathrm{ch}}$ is the partition coefficient of carbohydrate-water (Chiou et al., 2001).

Thus, the potato pesticide concentrations can be given by the equations

$C_{\mathrm{p}}(t)=\left\{\begin{array}{ccc}\frac{C_{\mathrm{w}}(0) k_{\mathrm{u}}\left(\mathrm{e}^{-k_{\mathrm{s}} t}-\mathrm{e}^{-\left(k_{\mathrm{e}}+k_{\mathrm{g}}\right) t}\right)}{\left(k_{\mathrm{e}}+k_{\mathrm{g}}-k_{\mathrm{s}}\right)} & \text { if } & k_{\mathrm{e}}+k_{\mathrm{g}} \neq k_{\mathrm{s}} \text { case } 1 \mathrm{a} \\ C_{\mathrm{w}}(0) k_{\mathrm{u}} t \mathrm{e}^{-k_{\mathrm{s}} t} & \text { if } & k_{\mathrm{e}}+k_{\mathrm{g}}=k_{\mathrm{s}} \text { case } 2 \mathrm{a}\end{array}\right.$

The BCF $\left(\mathrm{L} \mathrm{kg}^{-1}\right)$ in the steady state equilibrium can be determined using Eqs. (2) and (11) by

$\mathrm{BCF}=\lim _{t \rightarrow \infty}\left[\frac{C_{\mathrm{p}}(t)}{C_{\mathrm{w}}(t)}\right]=\left\{\begin{array}{ccc}\frac{k_{\mathrm{u}}}{k_{\mathrm{e}}+k_{\mathrm{g}}-k_{\mathrm{s}}} & \text { if } & k_{\mathrm{e}}+k_{\mathrm{g}}>k_{\mathrm{s}} \text { case } 1 \mathrm{~b} \\ +\infty & \text { if } & k_{\mathrm{e}}+k_{\mathrm{g}} \leqslant k_{\mathrm{s}} \text { case } 2 \mathrm{~b}\end{array}\right.$

that is, $\mathrm{BCF}(t)=C_{\mathrm{p}}(t) / C_{\mathrm{w}}(t)$ converges to a steady state as time tends to infinity if, and only if $k_{\mathrm{e}}+k_{\mathrm{g}}>k_{\mathrm{s}}$, Eq. $(12-$ case $1 \mathrm{~b})$. Eq. (12 - case $1 \mathrm{~b})$ demonstrates that finite BCF values depend on the pesticide uptake rate by potato, the pesticide elimination rate by potato, potato growth rate, and pesticide degradation rate in soil. Thus, BCF depends on the potato, pesticide and soil physical-chemical characteristics. In this paper we are assuming that $k_{\mathrm{e}}+k_{\mathrm{g}}>k_{\mathrm{s}}$, Eq. $(11-$ case $1 \mathrm{a}$ ) and Eq. (12 - case $1 \mathrm{~b})$.

It is important to observe that the condition $\mathrm{d} C_{\mathrm{p}} / \mathrm{d} t=0$ frequently used to estimate the steady state of equation Eq. (4) is true if, and only if the pesticide concentration in the medium is constant, in this case, $\mathrm{BCF}=\frac{k_{\mathrm{u}}}{\mathrm{k}_{\mathrm{e}}+\mathrm{kg}_{\mathrm{g}}}$. When the soil pesticide concentration is not constant the $\mathrm{d} C_{\mathrm{p}} / \mathrm{d} t=0$ determines an unstable equilibrium point of the $C_{\mathrm{p}}=C_{\mathrm{p}}(t)$.

Eq. (11 - case 1a)was used to estimate the required time to obtain the maximum pesticide concentration in the potato by $t_{\max }=\frac{\ln \left(k_{\mathrm{e}}+k_{\mathrm{g}}\right)-\ln \left(k_{\mathrm{s}}\right)}{k_{\mathrm{e}} k_{\mathrm{g}}-k_{\mathrm{s}}}$. The maximum pesticide concentration in potato was estimated by $C_{\mathrm{p}}^{\max }=C_{\mathrm{p}}\left(t_{\max }\right)\left(\mathrm{mg} \mathrm{L}^{-1}\right)$.

\subsection{Input date of the model}

Table 1 shows the potato and soil characteristics and Table 2 shows the pesticide parameters used in the model to estimate the BCF values. The octanol-water partition coefficient, water solubility, vapor pressure and molecular mass were obtained in the Syracuse Research Corporation (SRC, 2007). The molar volume was estimated using the ChemSketch 5.0 computer program (Advanced Chemistry Development/ACD, Inc., 2006). The soil sorption partition coefficient of the pesticide and the pesticide half-life in the soil values were obtained from Hornsby et al. (1996) or PETE model data base (Nicholls, 1994), or else, estimated by the EPISuite system (Table 2). The EPI (Estimation Programs Interface) EPI Suite ${ }^{\mathrm{TM}}$ is a Windows ${ }^{\circledR}$ based suite of physical-chemical prop-
Table 1

Potato plants and soil physical-chemical parameters applied to the model to estimate the bioconcentration factor of pesticides in potatoes (BCF)

\begin{tabular}{llll}
\hline Parameter & Symbol & Value & Unit \\
\hline Potato water volumetric content $^{\mathrm{a}}$ & $w_{\mathrm{p}}$ & 0.778 & $\mathrm{~g} \mathrm{~g}^{-1}$ \\
Potato lipid volumetric content $^{\mathrm{a}}$ & $l$ & 0.001 & $\mathrm{~g} \mathrm{~g}^{-1}$ \\
Potato carbohydrate volumetric content $^{\mathrm{a}}$ & $\mathrm{CH}_{\mathrm{p}}$ & 0.154 & $\mathrm{~g} \mathrm{~g}^{-1}$ \\
Potato growth rate $^{\mathrm{a}}$ & $k_{\mathrm{g}}$ & 0.139 & $\mathrm{day}^{-1}$ \\
Potato density $^{\mathrm{b}}$ & $\rho_{\mathrm{p}}$ & 1.10 & $\mathrm{~kg} \mathrm{~L}^{-1}$ \\
Average potato sphere-ray $^{\mathrm{a}}$ & $r$ & 0.04 & $\mathrm{~m}$ \\
Soil-organic carbon volumetric fraction $^{\mathrm{a}}$ & $f_{\mathrm{oc}}$ & 0.018 & $\mathrm{~g} \mathrm{~g}^{-1}$ \\
Soil-water volumetric fraction $^{\mathrm{a}}$ & $f_{\mathrm{w}}$ & 0.28 & $\mathrm{~g} \mathrm{~g}^{-1}$ \\
Soil-air volumetric fraction $^{\mathrm{a}}$ & $f_{\mathrm{a}}$ & 0.12 & $\mathrm{~g} \mathrm{~g}^{-1}$ \\
Soil density on humid base $^{\mathrm{a}}$ & $\rho_{\mathrm{w}}$ & 1.95 & $\mathrm{~kg} \mathrm{~L}^{-1}$ \\
Soil density on dry base $^{\mathrm{a}}$ & $\rho_{\mathrm{s}}$ & 1.60 & $\mathrm{~kg} \mathrm{~L}^{-1}$ \\
\hline
\end{tabular}

a Trapp et al. (2007).

b http://www.starch.dk/isi/starch/tm5www-potato.htm.

erty and environmental fate estimation models developed by the United States Environmental Protection Agency's Office of Pollution Prevention Toxics and Syracuse Research Corporation (http://www.epa.gov/opptintr/exposure/docs/episuite.htm).

In this study, the evaluated pesticides were selected through personal interviews with traditional Brazilian potato producers and were consulted on the Brazilian legally registered pesticide list for potato crop use (ANVISA, 2007). Due to the nature of the model, only pesticides with nonionic physical-chemical characteristics were selected for the simulations.

\section{Results and discussion}

The model given by Eq. (12 - case 1b)was developed to estimate potato pesticide BCF of soil degrading pesticides. For that, the potato pesticide uptake and elimination rates were supposed to be driven by passive diffusion processes in both soil solution and potatoes, intermediated by the soil, water or potato pesticides sorption coefficients. Moreover, the pesticide degradation in the soil and pesticide dilution in the potatoes was supposed to be described by first-order kinetic equations, Eqs. (1) and (4), respectively. Thus, the model assumes that the bioconcentration factor (BCF) of pesticides in potatoes is a result of the pesticide mass balance between pesticide concentration in the soil solution and pesticide concentration in the potato.

The pesticide lixiviation potential can be estimated through the empirical GUS index calculus, given by, GUS $=\left(4-\log K_{\mathrm{oc}}\right) \times$ $\log t_{1 / 2}$. Depending on the GUS index numerical value, the pesticide is classified as a leaching potential (GUS $\geqslant 2.8$ ), a non-leaching potential (GUS $\leqslant 1.8$ ) or an undetermined leaching potential pesticide (transient) $(1.8 \leqslant$ GUS $\leqslant 2.8)$ (Gustafson, 1989).

Six of the fifty studied pesticides (12\%) are potentially leaching pesticides. Thirty four (68\%) are potential non-leaching pesticides. And $10(20 \%)$ are transient or of undetermined leaching potential which means they might or might not be leaching pesticides (Table 3 ). The BCF varied between $0.0004 \mathrm{~L} \mathrm{~kg}^{-1}$ ( $\alpha$-cyfluthrin) and $1.3161 \mathrm{~L} \mathrm{~kg}^{-1}$ (methamidophos), indicating that the pesticide potato concentration is, at most, within the same concentration range or, at least, several ten-thousand times lower than the pesticide concentration in soil solution $\left(C_{\mathrm{p}}=C_{\mathrm{w}} \mathrm{BCF}\right)$.

Eq. (12 - case 1b) does not describe a first-order kinetics uptake and elimination process of pesticide for potato, but allows estimating the time in which the potato pesticide concentration is maximum, $t_{\max }$ (days), and the maximum potato pesticide concentration $C_{\mathrm{p}}\left(t_{\max }\right)$. An initial soil solution pesticide concentration of $1.0 \mathrm{mg} \mathrm{L}^{-1}\left(C_{\mathrm{w}}(0)=1.0 \mathrm{mg} \mathrm{L}^{-1}\right)$ would result in a potato concentration in $t_{\max }$ those are given in Table 3 . Such values $\left(t_{\max }\right.$ and $C_{\mathrm{p}}\left(t_{\max }\right)$ ) will provide information for planning potato 
Table 2

Pesticides and physical-chemical properties applied to the model to estimate the bioconcentration factor of pesticides in potatoes (BCF)

\begin{tabular}{|c|c|c|c|c|c|c|c|}
\hline Pesticide & Molar mass ${ }^{\mathrm{A}}\left(\mathrm{g} \mathrm{mol}^{-1}\right)$ & Vapor pressure $^{\mathrm{A}}(\mathrm{Pa})$ & Water solubility ${ }^{\mathrm{A}}\left(\mathrm{g} \mathrm{m}^{-3}\right)$ & $\log K_{\text {ow }}{ }^{\mathrm{A}}$ & $K_{\mathrm{oc}}^{\mathrm{B}}\left(\mathrm{L} \mathrm{kg}^{-1}\right)$ & Half-life $^{B}$ (days) & $K_{\mathrm{ch}}{ }^{\mathrm{C}}$ \\
\hline Aldicarb & 190.27 & $4.63 \mathrm{E}-03$ & 6030 & 1.13 & $30^{a}$ & $30^{\mathrm{a}}$ & 0.50 \\
\hline$\alpha$-Cypermethrin & 416.31 & $2.31 \mathrm{E}-05$ & 0.01 & 6.94 & $108000^{c}$ & $360^{c}$ & 3.00 \\
\hline Azoxystrobin & 403.40 & $1.10 \mathrm{E}-10$ & 6 & 2.50 & $143^{b}$ & $14^{\mathrm{b}}$ & 1.00 \\
\hline$\beta$-Cyfluthrin & 434.30 & $2.00 \mathrm{E}-08$ & 0.003 & 5.95 & $178600^{c}$ & $360^{c}$ & 3.00 \\
\hline Cadusafos & 270.40 & $1.20 \mathrm{E}-01$ & 248 & 3.90 & $767^{\mathrm{b}}$ & $45^{\mathrm{b}}$ & 2.00 \\
\hline Captan & 300.59 & $1.20 \mathrm{E}-05$ & 5.10 & 2.80 & $200^{a}$ & $3^{a}$ & 1.00 \\
\hline Carbaryl & 201.23 & $1.81 \mathrm{E}-04$ & 110 & 2.36 & $300^{a}$ & $10^{\mathrm{a}}$ & 1.00 \\
\hline Carbofuran & 221.26 & $6.47 \mathrm{E}-04$ & 320 & 2.32 & $22^{\mathrm{a}}$ & $50^{\mathrm{a}}$ & 1.00 \\
\hline Cartap & 273.81 & $9.40 \mathrm{E}-07$ & 89100 & -0.95 & $42^{c}$ & $75^{\mathrm{c}}$ & 0.10 \\
\hline Chlorfenapyr & 407.62 & $9.81 \mathrm{E}-06$ & 0.11 & 4.83 & $24160^{c}$ & $360^{c}$ & 3.00 \\
\hline chlorfluazuron & 540.66 & $1.21 \mathrm{E}-12$ & 0.0044 & 5.80 & $7457^{\mathrm{b}}$ & $50^{\mathrm{b}}$ & 3.00 \\
\hline Chlorothalonil & 265.91 & $7.60 \mathrm{E}-05$ & 0.60 & 3.05 & $1380^{a}$ & $30^{\mathrm{a}}$ & 2.00 \\
\hline Chlorpyrifos & 350.59 & $2.71 \mathrm{E}-03$ & 1.12 & 4.96 & $6070^{\mathrm{a}}$ & $30^{\mathrm{a}}$ & 3.00 \\
\hline Cymoxanil & 198.18 & $1.51 \mathrm{E}-04$ & 890 & 0.59 & $14^{\mathrm{b}}$ & $5^{\mathrm{b}}$ & 0.20 \\
\hline Cypermethrin & 416.31 & $4.09 \mathrm{E}-07$ & 0.004 & 6.60 & $100000^{a}$ & $30^{a}$ & 3.00 \\
\hline Deltamethrin & 505.21 & $2.00 \mathrm{E}-06$ & 0.002 & 6.20 & $12038^{a}$ & $40^{\mathrm{a}}$ & 3.00 \\
\hline Difenoconazole & 406.27 & $3.33 \mathrm{E}-08$ & 15 & 4.30 & $1098^{\mathrm{b}}$ & $120^{\mathrm{b}}$ & 3.00 \\
\hline Dimethoate & 229.26 & $1.10 \mathrm{E}-03$ & 25000 & 0.78 & $20^{\mathrm{a}}$ & $7^{\mathrm{a}}$ & 0.20 \\
\hline Dimethomorph & 387.87 & $9.84 \mathrm{E}-07$ & 18.70 & 2.68 & $182^{\mathrm{b}}$ & $10^{\mathrm{b}}$ & 1.00 \\
\hline Ethion & 384.48 & $2.00 \mathrm{E}-04$ & 2 & 5.07 & $10000^{a}$ & $150^{\mathrm{a}}$ & 3.00 \\
\hline Ethoprophos & 242.34 & $5.07 \mathrm{E}-02$ & 750 & 3.59 & $70^{\mathrm{a}}$ & $25^{\mathrm{a}}$ & 2.00 \\
\hline Famoxadone & 374.40 & $6.40 \mathrm{E}-07$ & 0.05 & 4.65 & $37760^{c}$ & $120^{c}$ & 3.00 \\
\hline Fenamiphos & 277.24 & $7.20 \mathrm{E}-03$ & 38 & 3.30 & $2000^{a}$ & $4^{\mathrm{a}}$ & 2.00 \\
\hline Fenthion & 278.33 & $1.40 \mathrm{E}-03$ & 7.50 & 4.09 & $1500^{\mathrm{a}}$ & $34^{\mathrm{a}}$ & 3.00 \\
\hline Fipronil & 437.15 & $3.71 \mathrm{E}-07$ & 1.90 & 4.00 & $3352^{c}$ & $360^{c}$ & 3.00 \\
\hline Fludioxonil & 248.19 & $3.91 \mathrm{E}-07$ & 1.80 & 4.12 & $998^{b}$ & $150^{\mathrm{b}}$ & 3.00 \\
\hline Folpet & 296.56 & $2.09 \mathrm{E}-05$ & 0.80 & 2.85 & $294^{\mathrm{a}}$ & $5^{a}$ & 1.00 \\
\hline Imidacloprid & 255.67 & $4.00 \mathrm{E}-10$ & 610 & 0.57 & $11^{\mathrm{b}}$ & $120^{\mathrm{b}}$ & 0.20 \\
\hline Iprodione & 330.17 & $5.00 \mathrm{E}-07$ & 13.90 & 3.00 & $700^{a}$ & $14^{\mathrm{a}}$ & 2.00 \\
\hline$\lambda$-Cyhalothrin & 449.86 & $2.00 \mathrm{E}-07$ & 0.0009 & 7.00 & $180000^{\mathrm{a}}$ & $30^{\mathrm{a}}$ & 3.00 \\
\hline Lufenuron & 511.16 & $1.11 \mathrm{E}-08$ & 0.06 & 5.12 & $3303^{b}$ & $15^{\mathrm{b}}$ & 3.00 \\
\hline Mancozeb & 541.03 & $1.76 \mathrm{E}-08$ & 6.20 & 1.33 & $2000^{\mathrm{a}}$ & $70^{\mathrm{a}}$ & 0.50 \\
\hline Metalaxyl & 279.34 & $3.31 \mathrm{E}-03$ & 26000 & 1.71 & $50^{\mathrm{a}}$ & $70^{a}$ & 0.50 \\
\hline Methamidophos & 141.13 & $4.71 \mathrm{E}-03$ & 1000000 & -0.80 & $5^{a}$ & $6^{a}$ & 0.10 \\
\hline Methidathion & 302.33 & $4.49 \mathrm{E}-04$ & 187 & 2.20 & $400^{\mathrm{a}}$ & $7^{\mathrm{a}}$ & 1.00 \\
\hline Parathion methyl & 263.21 & $4.67 \mathrm{E}-04$ & 37.70 & 2.86 & $523^{c}$ & $75^{c}$ & 1.00 \\
\hline Pencycuron & 328.85 & $5.00 \mathrm{E}-10$ & 0.30 & 4.82 & $8791^{c}$ & $75^{c}$ & 3.00 \\
\hline Phenthoate & 320.37 & $3.47 \mathrm{E}-04$ & 11 & 3.69 & $1000^{\mathrm{a}}$ & $35^{a}$ & 2.00 \\
\hline Phorate & 260.38 & $8.51 \mathrm{E}-02$ & 50 & 3.56 & $1000^{\mathrm{a}}$ & $60^{\mathrm{a}}$ & 2.00 \\
\hline Procymidone & 284.14 & $1.87 \mathrm{E}-02$ & 4.50 & 3.08 & $1500^{\mathrm{a}}$ & $7^{\mathrm{a}}$ & 2.00 \\
\hline Profenofos & 373.64 & $1.20 \mathrm{E}-04$ & 28 & 4.68 & $2000^{\mathrm{a}}$ & $8^{a}$ & 3.00 \\
\hline Propiconazole & 342.23 & $1.33 \mathrm{E}-04$ & 110 & 3.72 & $650^{\mathrm{a}}$ & $110^{\mathrm{a}}$ & 2.00 \\
\hline Prothiofos & 345.25 & $1.25 \mathrm{E}-03$ & 0.07 & 5.67 & $6382^{b}$ & $35^{\mathrm{b}}$ & 3.00 \\
\hline Quintozene & 295.34 & $6.67 \mathrm{E}-03$ & 0.44 & 4.64 & $2252^{b}$ & $200^{\mathrm{b}}$ & 3.00 \\
\hline Tebuconazole & 307.83 & $1.71 \mathrm{E}-06$ & 36 & 3.70 & $603^{b}$ & $120^{\mathrm{b}}$ & 2.00 \\
\hline Teflubenzuron & 381.12 & $8.00 \mathrm{E}-10$ & 0.02 & 4.56 & $1237^{b}$ & $20^{\mathrm{b}}$ & 3.00 \\
\hline Tetradifon & 356.06 & $3.20 \mathrm{E}-08$ & 0.08 & 4.61 & $1794^{\mathrm{b}}$ & $90^{\mathrm{b}}$ & 3.00 \\
\hline Tolylfluanid & 347.26 & $2.00 \mathrm{E}-04$ & 0.90 & 3.90 & $1728^{c}$ & $120^{c}$ & 2.00 \\
\hline Triazophos & 313.32 & $3.87 \mathrm{E}-04$ & 39 & 3.34 & $504^{\mathrm{b}}$ & $18^{\mathrm{b}}$ & 2.00 \\
\hline Triflumuron & 358.71 & $4.00 \mathrm{E}-08$ & 0.03 & 4.91 & $2569^{b}$ & $40^{\mathrm{b}}$ & 3.00 \\
\hline
\end{tabular}

A Values from SRC (2007).

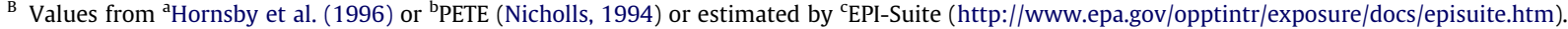

c Chiou et al. (2001).

pesticide monitoring programs regarding maximum allowed concentrations of pesticide would also be helpful for establishing safe strategies for potato crop management in a contaminated soil with pesticides.

In general pesticides with high soil sorption partition coefficient can be found sorbed in soil matrix making them unavailable for lixiviation or plant uptake. On the other hand, pesticides with high water solubility are theoretically the most available ones to bioconcentrate into potatoes, due to their high water diffusivity and low soil sorption partition coefficient. Apart from that, pesticides with relatively high soil half-life and low soil sorption partition coefficient are classified as potential leaching pesticides because of their GUS index values (Table 3).

Considering the GUS index, soil sorption partition coefficient of the pesticide, $K_{\mathrm{oc}}$ and BCF values all together, methamidophos, cymoxanil, imidacloprid, dimethoate, carbofuran, aldicarb, etho- prophos, cartap, metalaxyl, fenamiphos, azoxystrobin, tebuconazole, propiconazole, cadusafos, fludioxonil, parathion methyl and difenoconazole are the priority pesticides to be monitored in potatoes. Although Rissato et al. (2005) have found $0.092 \mathrm{mg} \mathrm{kg}^{-1}$ of chlorothalonil, $0.013 \mathrm{mg} \mathrm{kg}^{-1}$ of tebuconazole and $0.022 \mathrm{mg} \mathrm{kg}^{-1}$ of cypermethrin in commercial potato samples, such pesticide concentrations probably occurred because of the high pesticide concentrations in soil solution estimated by $\left(C_{\mathrm{w}}=C_{\mathrm{p}} / \mathrm{BCF}\right)$ $\left(C_{\text {tebuconazole }}=0.27 \mathrm{mg} \mathrm{L}^{-1} ; C_{\text {chlorothalonil }}=4.87 \mathrm{mg} \mathrm{L}^{-1} ; C_{\text {cypermethrin }}=\right.$ $27.5 \mathrm{mg} \mathrm{L}^{-1}$ ), which was not experimentally verified by Rissato et al. (2005).

Fig. 1 shows the relationship between $\log K_{\mathrm{oc}}$ (the logarithm of soil sorption partition coefficient) and $\log B C F$ (the logarithm of bioconcentration factor). The empirical regression model obtained was $\log \mathrm{BCF}=0.85( \pm 0.06)-0.78( \pm 0.02) \quad \log K_{\mathrm{oc}}(n=50)$ with $R$ squared $=0.97 \%$, correlation coefficient $=-0.98$ and $p<0.001$, indi- 
Table 3

Bioconcentration factor (BCF), time of the maximum potato pesticide concentration $t_{\text {max }}$, maximum potato pesticide concentration $C_{\mathrm{p}}\left(t_{\text {max }}\right)$, GUS index and lixiviation classes

\begin{tabular}{|c|c|c|c|c|c|}
\hline Pesticide & $\mathrm{BCF}\left(\mathrm{L} \mathrm{kg}^{-1}\right)$ & $t_{\max }$ (days) & $C_{\mathrm{p}}\left(t_{\max }\right) C_{\mathrm{w}}(0)=1.0 \mathrm{mg} \mathrm{L}^{-1}$ & GUS & Lixiviation class \\
\hline Methamidophos & 1.3161 & 2 & 0.8837 & 2.57 & Transient \\
\hline Cymoxanil & 0.8530 & 3 & 0.4982 & 1.99 & Transient \\
\hline Imidacloprid & 0.8192 & 6 & 0.7855 & 6.15 & Leaching \\
\hline Dimethoate & 0.6415 & 3 & 0.4162 & 2.28 & Transient \\
\hline Carbofuran & 0.6294 & 6 & 0.5650 & 4.52 & Leaching \\
\hline Aldicarb & 0.4543 & 5 & 0.3942 & 3.73 & Leaching \\
\hline Ethoprophos & 0.3894 & 7 & 0.2965 & 3.01 & Leaching \\
\hline Cartap & 0.3193 & 6 & 0.2994 & 4.46 & Leaching \\
\hline Metalaxyl & 0.2886 & 7 & 0.2657 & 4.25 & Leaching \\
\hline Fenamiphos & 0.2283 & 8 & 0.1966 & 3.40 & Leaching \\
\hline Captan & 0.1629 & 3 & 0.0553 & 0.81 & Non-leaching \\
\hline Azoxystrobin & 0.1349 & 5 & 0.0947 & 2.11 & Transient \\
\hline Dimethomorph & 0.1152 & 5 & 0.0714 & 1.74 & Non-leaching \\
\hline Folpet & 0.0913 & 3 & 0.0460 & 1.07 & Non-leaching \\
\hline Carbaryl & 0.0714 & 4 & 0.0493 & 1.52 & Non-leaching \\
\hline Methidathion & 0.0555 & 3 & 0.0335 & 1.18 & Non-leaching \\
\hline Triazophos & 0.0549 & 6 & 0.0393 & 1.63 & Non-leaching \\
\hline Tebuconazole & 0.0481 & 12 & 0.0441 & 2.54 & Transient \\
\hline Teflubenzuron & 0.0465 & 10 & 0.0280 & 1.18 & Non-leaching \\
\hline Propiconazole & 0.0461 & 12 & 0.0421 & 2.42 & Transient \\
\hline Cadusafos & 0.0440 & 10 & 0.0359 & 1.84 & Transient \\
\hline Fludioxonil & 0.0432 & 13 & 0.0400 & 2.18 & Transient \\
\hline Profenofos & 0.0430 & 7 & 0.0134 & 0.63 & Non-leaching \\
\hline Parathion methyl & 0.0406 & 7 & 0.0374 & 2.40 & Transient \\
\hline Iprodione & 0.0368 & 5 & 0.0254 & 1.32 & Non-leaching \\
\hline Difenoconazole & 0.0368 & 16 & 0.0328 & 1.99 & Transient \\
\hline Phenthoate & 0.0307 & 9 & 0.0245 & 1.54 & Non-leaching \\
\hline Tetradifon & 0.0292 & 16 & 0.0250 & 1.46 & Non-leaching \\
\hline Phorate & 0.0290 & 9 & 0.0254 & 1.78 & Non-leaching \\
\hline Fenthion & 0.0274 & 10 & 0.0209 & 1.26 & Non-leaching \\
\hline Quintozene & 0.0262 & 18 & 0.0243 & 1.49 & Non-leaching \\
\hline Triflumuron & 0.0242 & 14 & 0.0173 & 0.95 & Non-leaching \\
\hline Lufenuron & 0.0224 & 11 & 0.0100 & 0.57 & Non-leaching \\
\hline Procymidone & 0.0203 & 4 & 0.0110 & 0.70 & Non-leaching \\
\hline Tolylfluanid & 0.0195 & 12 & 0.0178 & 1.59 & Non-leaching \\
\hline Chlorothalonil & 0.0189 & 6 & 0.0158 & 1.27 & Non-leaching \\
\hline Prothiofos & 0.0124 & 15 & 0.0080 & 0.30 & Non-leaching \\
\hline Chlorpyrifos & 0.0110 & 13 & 0.0072 & 0.32 & Non-leaching \\
\hline Fipronil & 0.0108 & 17 & 0.0104 & 1.21 & Non-leaching \\
\hline Mancozeb & 0.0089 & 6 & 0.0084 & 1.29 & Non-leaching \\
\hline Chlorfluazuron & 0.0088 & 18 & 0.0063 & 0.22 & Non-leaching \\
\hline Pencycuron & 0.0062 & 17 & 0.0051 & 0.10 & Non-leaching \\
\hline Deltamethrin & 0.0060 & 17 & 0.0039 & -0.13 & Non-leaching \\
\hline Ethion & 0.0056 & 21 & 0.0050 & 0.00 & Non-leaching \\
\hline Chlorfenapyr & 0.0022 & 24 & 0.0021 & -0.98 & Non-leaching \\
\hline Famoxadone & 0.0013 & 18 & 0.0011 & -1.20 & Non-leaching \\
\hline Cypermethrin & 0.0008 & 15 & 0.0005 & -1.48 & Non-leaching \\
\hline$\alpha$-Cypermethrin & 0.0006 & 31 & 0.0006 & -2.64 & Non-leaching \\
\hline$\lambda$-Cyhalothrin & 0.0004 & 15 & 0.0002 & -1.85 & Non-leaching \\
\hline$\beta$-Cyfluthrin & 0.0004 & 30 & 0.0003 & -3.20 & Non-leaching \\
\hline
\end{tabular}

cating a liner regression and a negative correlation between the dependent variable $(\log \mathrm{BCF})$ and the independent variable (log$K_{\mathrm{oc}}$ ). $\log K_{\mathrm{oc}}$ had good correlation with $\log$ BCF. Zohair et al. (2006) also pointed out that the polyaromatic hydrocarbon (PAH) BCF's in potatoes may decrease when the $K_{\text {ow }}$ value increases, which for $\mathrm{PAH}$ is equivalent to the soil sorption partition coefficient increase.

Furthermore, the BCF value permits an approximation of the pesticide's daily intake (DI) per body weight by consumption of potatoes cultivated in pesticide contaminated soils, and establishing environment pesticide acceptable limits for agricultural use. For example a soil solution supposed to contain $1.0 \mathrm{mg} \mathrm{kg}^{-1}$ of methamidophos result a potato pesticide concentration of $1.3161 \mathrm{mg} \mathrm{kg}^{-1}\left(C_{\mathrm{p}}=C_{\mathrm{w}} \mathrm{BCF}\right)$ and a daily intake of $0.0094 \mathrm{mg} \mathrm{kg}^{-1}$ ( $\mathrm{mg}$ of methamidophos per $\mathrm{kg}$ body weight, considering a $70 \mathrm{~kg}$ body weight person with a daily potato consumption of $0.5 \mathrm{~kg}$ ), calculated by $\mathrm{DI}=0.5 \times C_{\mathrm{p}} / 70$. This $\mathrm{DI}$ value would be 188 times higher than the reference dose (RfD) of $5.0 \times 10^{-5} \mathrm{mg} \mathrm{kg}^{-1} \mathrm{day}^{-1}$, defined by EPA for methamidophos (EPA, http://www.epa.gov/ iris/subst/0250.htm). On the overall, RfD is an estimate of human daily exposition to chemical agents that would not present a health injury risk along a lifetime and it is expressed in milligrams of chemical agents per $\mathrm{kg}$ body weight per day $\left(\mathrm{mg} \mathrm{kg}^{-1} \mathrm{day}^{-1}\right.$ ) (EPA, 2007).

Therefore, potatoes treated with pesticides must be monitored for pesticide concentration and, in theory, when consumed they should not present pesticide concentrations above the RfD value. Or, for instance, soil methamidophos concentrations higher than $5.3 \times 10^{-3} \mathrm{mg} \mathrm{kg}^{-1}\left(C_{\mathrm{w}(\text { estimated })}=70 \times \mathrm{RfD} /(0.5 \times \mathrm{BCF})\right)$ should be avoided, because such values might result in potato pesticide concentrations which are higher than the methamidophos RfD value. Wu et al. (2001) reported three clinical cases of human poisoning caused by consumption of methamidophos-contaminated vegetables, including sweet-potatoes. It is important to point out that the pesticide $\mathrm{BCF}$ values from Table $3\left(\log K_{\mathrm{ow}} \geqslant 4.0\right)$ are in the same BCF value range of the polyaromatic hydrocarbons (PAH) 


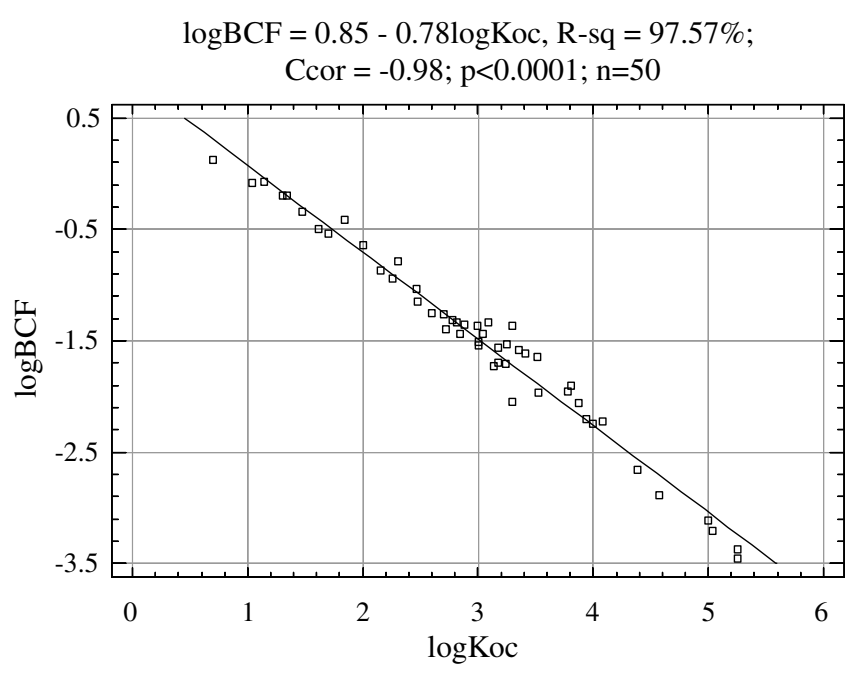

Fig. 1. Linear regression equation for the relationship between the logarithm of soil pesticide sorption coefficient $\left(\log K_{\mathrm{oc}}\right)$ and the logarithm of bioconcentration factor of pesticides in potatoes ( $\log \mathrm{BCF}$ ) estimated by the potato pesticide bioconcentration model.

$\left(\log K_{\mathrm{ow}} \geqslant 4.0\right)$ experimentally observed in potatoes by Fismes et al. (2002) and Samsoe-Petersen et al. (2002). No other experimental potato pesticide BCF values have been reported.

\section{Conclusions}

A potato pesticide bioconcentration model is presented to estimate the BCF values of soil degrading nonionic pesticides. The $\mathrm{BCF}$ model expression depends directly on the potato pesticide uptake rate, and inversely, on the potato pesticide elimination rate, potato growth rate, and soil pesticide degrading rate. By means of the potato pesticide bioconcentration factor and soil sorption partition coefficient, it is possible to point out the existence of a negative linear correlation between the logarithms of the soil sorption partition coefficient and the logarithms of BCF. The potato BCF were estimated for about 50 pesticides and a priority pesticide group was suggested to be monitored in potatoes. The pesticide daily intake by potato consumption estimate, the establishment of soil pesticide safe limits for potato cropping and the selection of pesticides for potato sample monitoring can be accomplished using the bioconcentration factor values. Mathematical models can contribute to forecasting pesticide concentrations and suggesting which pesticides should have priority and which should be systematically monitored in potato samples. Field and laboratory experiments must be conducted in order to test and validate the present model.

\section{Acknowledgements}

Financial support for this research was provided by Embrapa (Empresa Brasileira de Pesquisa Agropecuária) Grant Number MP3/ 03065100001, Fapesp (Fundação de Amparo á Pesquisa do Estado de São Paulo) Grant Number 2007/44280-8, and CNPq for the researcher formation of scientific initiation scholarship PIBIC (119791/2007-2) and EMBRAPA (800002/1996-2).

\section{References}

ACD/ChemSketch Freeware, version 5.0, Advanced Chemistry Development, Inc. Toronto, ON, Released in: 2006. <http://www.acdlabs.com> (accessed 30.09.07).

ANVISA (Agência Nacional de Vigilância Sanitária), 2007. Agrotóxicos e Toxicologia: monografias de produtos agrotóxicos. <http://www.anvisa.gov.br/toxicologia/ monografias/index.htm> (accessed 20.08.07).

Caldas, E.D., Miranda, M.C.C., Conceição, M.H., Souza, L.C.K.R., 2004 Dithiocarbamates residues in Brazilian food and the potential risk for consumers. Food Chem. Toxicol. 42 (11), 1877-1883.

Cesnik, H.B., Gregorcic, A., Bolta, S.V., Kmecl, V., 2006. Monitoring of pesticide residues in apples, lettuce and potato of the Slovegne origin, 2001-04. Food Addit. Contam. 23 (2), 164-173.

Chiou, C.T., Sheng, G., Manes, M., 2001. A partition-limited model for the plant uptake of organic contaminants from soil and water. Environ. Sci. Technol. 35 (7), 1437-1444

Clark, M.M., 1996. Transport Modeling for Environmental Engineers and Scientists. Wiley-Interscience Publication, New York.

Crank, J., 1975. The mathematics of diffusion, second ed. Clarendon Press, Oxford. p. 414.

Dogheim, S.M., El-Marsafy, A.M., Salama, E.Y., Gadalla, A.S., Nabil, Y.M., 2002. Monitoring of pesticide residues in Egyptian fruits and vegetables during 1997. Food Addit. Contam. 19 (11), 1015-1027.

EPA, 1996. Ecological Effects Test Guidelines: OPTS 850.730 Fish BCF. EPA, Washington, DC.

Fismes, J., Perrin-Ganier, C., Empereur-Bissonnet, P., Morel, J.L., 2002. Soil-to-root transfer and translocation of polycyclic aromatic hydrocarbons by vegetables grown on industrial contaminated soils. J. Environ. Qual. 31, 1649-1656.

Gustafson, D.I., 1989. Groundwater ubiquity score: a simple method for assessing pesticide leachability. Environ. Toxicol. Chem. 8, 339-357.

Hornsby, A.G., Don Wauchope, R., Herner, A.E., 1996. Pesticide Properties in the Environment. Springer-Verlag, Inc., New York.

IBGE (Fundação Instituto Brasileiro de Geografia e Estatística), 2008. Produção Vegetal. Anu Estat Brasil. <http://www.ibge.gov.br/home/>.

Jensen, A.F., Petersen, A., Granby, K., 2003. Cumulative risk assessment of the intake of organophosphorus and carbamate pesticides in the Danish diet. Food Addit. Contam. 20 (8), 776-785.

Leistra, M., Van Den Berg, F., 2007. Volatilization of parathion and chlorothalonil from a potato crop simulated by the PEARL model. Environ. Sci. Technol. 41 (7), 2243-2248.

López-Pérez, G.C., Arias-Estévez, M., López-Periago, E., Soto-González, B., CanchoGrande, B., Simal-Gándara, J., 2006. Dynamics of pesticides in potato crops. J. Agric. Food Chem. 54, 1797-1803.

Nicholls, P.H., 1994. Physicochemical evaluation: the environment, and expert system for pesticide preregistration assessment. In: Proc. meet Brighton Crop Protection Conference: Pests and Diseases. (Organised by) British Crop Protection Council, Brighton, England, vol. 3, pp. 1337-1342.

OECD (Organization for Economic Cooperation and Development), 1996 Bioconcentration: flow-through fish test. OECD guidelines for the testing chemicals n 305, Paris, France.

Paraíba, L.C., 2007. Pesticide bioconcentration modelling for fruit trees Chemosphere 66 (8), 1468-1475.

Poulsen, M.E., Andersen, J.H., 2003. Results from the monitoring of pesticide residues in fruit and vegetables on the Danish market, 2000-01. Food Addit. Contam. 20 (8), 742-757.

Rissato, S.R., Galhiane, M.S., Apon, B.M., 2005. Development of a supercritical fluid extraction method for simultaneous determination of organophosphorus, organohalogen, organonitrogen and pyretroids pesticides in fruit and vegetables and its comparison with a conventional method by GC-ECD and GC-MS. J. Braz. Chem. Soc. 16 (5), 1038-1047.

Samsoe-Petersen, L., Larsen, E.H., Larsen, P.B., Bruun, P., 2002. Uptake of trace elements and PAHs by fruit and vegetables from contaminated soils. Environ. Sci. Technol. 36 (14), 3057-3063.

SRC (Syracuse Research Corporation), 2007. <http://www.syrres.com/esc/ physdemo.htm> (accessed 20.08.07).

Trapp, S., Cammarano, A., Capri, E., Reichenberg, F., Mayer, P., 2007. Diffusion of PAH in Potato and carrot slices and application for a potato model. Environ. Sci. Technol. 41 (9), 3103-3108.

Wu, M.L., Deng, J.F., Tsai, W.J., Ger, J., Wong, S.S., Li, H.P., 2001. Food poisoning due to methamidophos-contaminated vegetables. J. Toxicol. Clin. Toxicol. 39 (4), 333336.

Zohair, A., Salim, A.B., Soyibo, A.A., Beek, A.J., 2006. Residues of polycyclic aromatic hydrocarbons (PAHs), polychlorinated biphenyls (PCBs) and organochlorine pesticides in organically-farmed vegetables. Chemosphere 63 (4), 541-553. 